\title{
THE DUTCH COLONIAL POLICY ON ISLAM Reading the Intellectual Journey of Snouck Hurgronje
}

\author{
Jajat Burhanudin \\ Syarif Hidayatullah State Islamic University Jakarta, Indonesia \\ email:j.burbanudin@uinjkt.ac.id
}

\begin{abstract}
This article will explore the intellectual journey of Snouck Hurgonje as a bired scholar for the colonial agenda. His life in Mecca and then the Indies, his knowledge on Islam and the Muslims as revealed in the works he produced, and the way it was transformed into the colonial policies, are the main subjects of the discussion. The way Snouck. Hurgronje dealt with Muslims on his tour of duty, for example by collaborating with the penghulu, and working together with the Arab, Said Oesman, will also be explored. It should be stated that, in line with Snouck. Hurgonje's advice, the Dutch policy on Islam was directed (among other things) to draw the native elite --in this particular case the penghulu-- into the colonial orbit.
\end{abstract}

[Artikel ini membahas perjalanan intelektual Snouck Hurgonje, seorang ilmuwan yang bekerja di bawah dan untuk kepentingan colonial Belanda di Indonesia. Kehidupannya di Mekah, kemudian kembali lagi ke Indonesia, pengetahuannya tentang agama dan orang Islam yang tertuang dalam keryakaryanya, serta prosespengetahuan itu semua dalam mempengarubi kebijakan pemerintab kolonial menjadi tema utama diskusi dalam tulisan ini. Selain itu, akan dibahas pula cara-cara Snouck Hurgonje dalam berbubungan dengan orang-orang Islam selama menjalani tugasnya, misalnya ketika bekerjasama dengan para penghulu atau ketika bekerjasama dengan tokoh Arab, Said Oesman. Perlu ditegaskan pula bahwa sejalan dengan saran-saran Snouck Hurgonje, kebijakan pemerintah kolonial Belanda tentang Islam antara lain lebih ditujukan untuk menarik kalangan elit pribumi, dalam hal ini adalah para penghulu, ke lingkaran pemerintah kolonial.] 
Jajat Burhanudin

Keywords: Snouck Hurgronje, Said Oesman, penghulu, Dutch colonial policy.

\section{A. Introduction: Few Examples of Anti-Colonial Activism}

During the nineteenth century, as the creation of the colony in the Indies (the Dutch East Indies) progressed, encounters with Islamic affairs by the Dutch intensified. Next to military technology, and communication facilities --road, rail, telegraph and steamship-- the issues related to Islam and Muslims emerged as important considerations for the Dutch in their efforts to extend control in the Indies through their colonial administration. As a result, sufficient knowledge on the subject of Islam --to be more precise the nature of the influence of the bajj-was crucially needed, on the foundation of which the Dutch formulated policies pertinent to Islamic issues in the region.

In this respect, the role Christian Snouck Hurgronje (1857-1936) held is of great importance. He was a leading Dutch scholar who dedicated his intellectual capacity to the colonial power, and hence was an intellectual mastermind behind Dutch policies on Islam. In addition to knowing and understanding the religion, Snouck Hurgronje provided Dutch authorities with insights into ways to colonize Islam and the Muslims, and which eventually enabled them to penetrate the sociopolitical lives of the Indies people --the role which was embodied in the special office, het Kantoor voor Inlandsce en Arabische Zaken. It was in this office that he spent most of his career life.

Let me start the discussion with a brief look at some events that occurred prior to Snouck Hurgonje being hired by the colonial service. It appears that the rising protest movement, with Islam as a source of ideology, was the main reason the Dutch sought intellectual back up in dealing with Islamic issues in the nineteenth century.

The Banten Revolt of 1888 was significant. The work of Kartodirdjo describes the crucial role of Islam-related factors, especially through the engagement of ulama --with their pesantrens and tarekat-- in the movement. The leading ulama of Banten of the period, such as Hadji Abdul Karim, Hadji Tubagus Ismail, Hadji Mardjuki, and Hadji Wasid, constituted the main leaders who led the revolt and legitimized it as a jihad (Ar. jiha ad, holy war) against the colonial government. ${ }^{1}$ What

${ }^{1}$ Sartono Kartodirdjo, The Peasant Revolt of Banten in 1888: Its Conditions, Courses, and Sequel (The Hague: Martinus Nijhoff, 1966), pp. 177-92. 
is more important to grasp, however, is that the ulama mentioned had experience studying in Mecca, and hence their involvement as the ardent champions of the revolt proceeded alongside their engagement in the shari'ah-oriented reform project of "strengthening the moral and religious fibre of their society, combating laxity of conduct, and attempting to restore the Islamic ideal in all its original austerity", ${ }^{2}$ the main Islamic discourse transmitted from Mecca to the Indies in the nineteenth century.

Another important example of Islamic anti-colonial activism in the Indies was the Aceh War (1873-c.1910). This case best represents the Islamic threat to the Dutch government in the late nineteenth century. ${ }^{3} \mathrm{It}$ is not the intention of this article to go into detail about this war. What is of special importance is the fact that Islam played a major role in the struggle against the Dutch military forces. As in the case of Banten revolt, the role of Islam is to be explained from the involvement of ulama of dayah in the war. When the Dutch military forces embarked in March 1873, the Acehnese ulama took a leading position. Such prominent ulama as Teungku Chik di Tiro, Teungku Chik Kutakarang, and Teungku Tapa --to mention only a few-- emerged as the architects of war. They propagated the spirit of jihad, persuading the Acehnese to wage holy war against the disbelieving Dutch. ${ }^{4}$

The above historical examples, along with many others that are not mentioned, strongly demonstrate the crucial roles of Islam and Muslim leaders in the political arena, and eventually the Islamic anti-colonial activism in the nineteenth century. More importantly, the above examples also demonstrate the importance of the network with the Middle East that contributed to heightening anti-colonial sentiment and directing that sentiment to become anti-colonial movements, especially in the case of the Java War. The returned ulama from Mecca became the main agents who provided the anti-colonial protests with religious justification, alongside their reform of implementing shari'ah in Muslims' socio-religious life. Hence, the network with the Middle East became the source of colonial fears, which constituted one leading issue of the Dutch colonial

$2{ }^{I b} i d .$, p. 149.

${ }^{3}$ Michael F. Laffan, Islamic Nationhood and Colonial Indonesia: The Umma Below the Winds (London: Taylor \& Francis, 2003), pp. 39-43. For extensive studies on the Aceh War, see: Paul van 't Veer, Perang Aceh: Kisah Kegagalan Snouck Hurgronje (Jakarta: Grafitipers, 1985); T. Ibrahim Alfian, Perang di Jalan Allah, Perang Aceh 1873-1912 (Jakarta: Pustaka Sinar Harapan, 1987).

${ }^{4}$ Alfian, Perang di Jalan Allah, pp. 152-70. 
Jajat Burhanudin

discourses on Islam. ${ }^{5}$ For the Dutch colonial powers, Mecca was believed as the centre of an international conspiracy inspiring the spirit of anticolonial movements in the Muslim world.

Such colonial knowledge of Mecca developed at a time of the growing tide of the transmission of Islam to the Indies, in which anticolonial sentiment constituted one important issue. Late nineteenth century-Mecca provided the Jawi ${ }^{6}$ with the opportunity to learn from Arab ulama and live in an Islamic international milieu. In Mecca, the Jawi became familiar with Muslims from India, Africa and other countries in the Middle East. It was due to their close contact with international Muslims that anti-colonial sentiment was heightened. Under the colonial circumstances in their own countries of origin, this anti-colonial sentiment was then transformed into religious ideology of protest movements (jihad), spurred by a strong hatred for the kafir Dutch, while their spirit for religious learning and practices was strongly revived. ${ }^{7}$

The reasoning behind such a conclusion on Mecca was not without basis. In the late eighteenth century, Mecca became the bastion of a puritan movement of the Wahhābī. The Wahhābī movement came to the Islamic political and intellectual stage of Mecca, and more importantly, inspired the rise of what is called as pre-modern movement of Islamic reform. ${ }^{8}$ One salient feature of this movement was its strong enforcement, even radical in manner, of the application of shari'ah. Influenced in part by the religious ideas of Ibn Taymiyya (1263-1328), and in alliance with the Sa'ūd dynasty of Najd, Muhammad ibn 'Abd Wahhāb (1703-87) --the Wahhābī movement leader-- reforms were launched which called for a return to the true Islam based on the original sources (the Qur'an and the Sunnah) through which the reconstruction of Muslim society could be attained. ${ }^{9}$

The Mecca inspired spirit of movement can also be found in the ulama of Aceh. The aforementioned 'älim Teungku Chik di Tiro, for

${ }^{5}$ Kees van Dijk, "Colonial Fear: the Netherlands Indies and Malay Peninsula 1890-1918: Pan-Islamism and the Germano-Indian Plot", in Transcending borders: Arabs, politics, trade and Islam in Southeast Asia, ed. by H. de Jonge and N. Kaptein (Leiden: KITLV Press, 2002), pp. 53-89.

${ }^{6}$ Jawi was widely used in Islamic-classical era to refer people from South East Asian regions, such as Thailand, the Philippines, Vietnam, Malaysia, Indonesia, et cetera. They speak Malay as their lingua franca written in Arabic alphabets known as Jawi script.

${ }^{7}$ Kartodirdjo, The Peasant Revolt, pp. 148-9.

${ }^{8}$ Fazlur Rahman, Islam (Chicago: University of Chicago Press, 1966), pp. 196-201.

${ }^{9}$ Ibid., p. 200. 
instance, showed that he was not only familiar with the emerging anticolonial movement throughout the Muslim world, but also took it as an ideological source for his campaign for the Acehnese to fight against the Dutch military forces. In a letter to the Acehnese uleebalang (who had already sided with the Dutch), Teungku Chik di Tiro stressed his intention of continuously fighting against the Dutch and their Acehnese allies, noting that his struggle was in the path of Allah (fi sabil Alläh) and following Imam Mahdi "who was born in Sudan and Egypt and is struggling for the countries". ${ }^{10}$

There aren't any clues of a direct connection between Chik di Tiro and the Meccan circle except that he once visited Mecca for the pilgrimage. ${ }^{11}$ Yet, considering the international flavour of Mecca, it is more likely that it was through the Jawi community that the spirit of Imam Mahdi came to his knowledge. The Jawi were relatively well informed concerning the issues of Islamic affairs in their home as well as in international Muslim countries. Snouck Hurgronje recalled the occasion of an Acehnese joining the Jawi. The Javanese, who formed one segment of the Jawi in Mecca, posed questions dealing with the progress of events in his country. They were also involved in a discussion in which the struggle of the Sudanese against the English, and what Chik di Tiro did in Aceh, became debated issues. ${ }^{12}$

With this in mind, it is obvious that the heightened inclination towards shari'ah-oriented Islam, in line with its intensified connections with the Middle East, was coupled with the growth of anti-colonial activism in the Indies. Mecca, viewed by the Dutch as the centre of the Islamic conspiracy to overthrow the Dutch colonial powers, became one of the most important themes of Islamic affairs for the Dutch in the Indies. The ulama were viewed as being responsible for laying down a

${ }^{10}$ This letter of Teungku Chik di Tiro, dated 1885, can be found in manuscript in Leiden University Library (Cod. Or. 7321), which was then reprinted in "En Atjehsche Proclamatie" IG (1885: I, 665-7). See also: Alfian, Perang di Jalan Allah, pp. 152-61. Without mentioning Imam Mahdi, the campaign to wage the war was also evident in a letter of another Acehnese 'älim, Banta Muda Tuanku Hasyim bin Tuanku Nadir, dated 18 April 1871. See: W. Frijling, De Voornaamte Gebeurtenissen in het Begin van de 2de AtjehExpeditie, Door Atjehers Beschrieven, vol. 2 (1912), pp. 23-6; Abu Bakar (ed.), Surat-Surat Penting: Tuanku Hasyim Bangta Muda, Teungku Cbi di Tiro, dan Teuku Umarpada Masa Perang Kolonial Belanda di Aceh (Banda Aceh: Pusat Dokumentasi dan Informasi Aceh, 1978).

${ }^{11}$ Ismail Jakub, Teungku Tjbik Dhi-Tiro (Muhammad Saman): Pablawan Besar dalam Perang Aceh (1881-1891) (Jakarta: Bulan Bintang, 1960), p. 52.

${ }^{12}$ C. Snouck Hurgronje, Mekek in the Latter Part of the 19th Century (Leiden: E.J. Brill, 1931), pp. 245-6. 
Jajat Burhanudin

religious foundation of anti-colonial sentiment, which then transformed into an ideology of jihad that existed behind the revolts against colonial powers.

For this reason, the project of colonizing Islam began to be launched by the Dutch, with Mecca as the point of its departure. Snouck Hurgonje was the scholar with the task of comprehending the Indies pilgrims in Mecca, whom the Dutch suspected of being responsible for transmitting anti-Dutch ideology.

\section{B. Knowing Islam: A Mission to Mecca}

It was J.A. Kruijt, then the Dutch Consul in Jeddah, who nominated the young scholar of Leiden, Snouck Hurgonje, graduate from Leiden University with a doctoral dissertation on the haij, Het Mekkaansch Feest (1880), to be involved in the study of Indies pilgrims. In a letter he wrote to the Ministry of Foreign Affairs, 7 May 1884, Consul Kruijt, who was on leave in Holland, recommended Snouck Hurgronje to conduct the mission, as he himself was fully occupied with so many works other than supervising the Indies pilgrims. Kruijt, moreover, guaranteed, in a letter dated 23 May 1884, that he would be responsible for Snouck Hurgronje's Malay language training. This was a response to the Minister of Colonies, J.P. Sprenger van Eyck, who was at first in doubt of Snouck Hurgronje's capabilities in dealing with the pilgrims. ${ }^{13}$

Bolstered by the increasingly colonial fears of pan-Islamism in the Netherlands Indies, ${ }^{14}$ while comprehensive data on the impacts of bajj on the Indies Muslims was scant --as the information Kuijt reported from Jeddah "did not appear to be trustworthy"15-- J.P. Sprenger van Eyck finally accepted and agreed to what Kruijt proposed. Thus, Snouck Hurgronje was officially appointed. He left for Mecca in 1884 with $f 1500$ provided by the Dutch government for his tour to learn about the Indies pilgrims. ${ }^{16}$ He stayed in the holy city for almost one year.

This Meccan experience provided Snouck Hurgronje with extensive knowledge on the complexity of community life and Islamic learning

${ }^{13}$ P. Sj. van Koningsveld, Snouck Hurgronje dan Islam: Delapan Karangan tentang Hidup dan Karya Seorang Orientalis Zaman Kolonial, 1st edition (Jakarta: Girimukti Pasaka, 1989), pp. 67-70; Laffan, Islamic Nationhood, pp. 54-5.

${ }^{14}$ Dijk, "Colonial Fear", pp. 55-64.

${ }^{15} \mathrm{~J}$. Schmidt, Through the Legation Window, 1876-1926: Four Essays on Dutch, DutchIndian and Ottoman History (Istanbul: Nederlands Historisch-Archaeologisch Instituut te Istanbul, 1992), p. 74.

${ }^{16}$ Koningsveld, Snouck Hurgronje dan Islam, pp. 71-2. 
in this city. Beyond this, it also gave him opportunities to have direct contact and personal communication with the Indies Muslims residing in Mecca, the Jawi, as J.P. Sprenger van Eyck expected. With the support and assistance of his native informant from Banten, Raden Aboe Bakar Djajadiningrat, Snouk Hurgonje delved into the socio-intellectual and religious life of the Jawi. With the materials he received from Aboe Bakar, his Meccan experience was recounted and then appeared in his book Mekka (1931), which comprehensively describes the lives of the Jawi. ${ }^{17}$ With this, Snouck Hurgronje provided the mainly Dutch audiences with a new outlook on the Indies pilgrims and eventually on Islam.

It is beyond this research to delve into the controversial issues surrounding the ethico-intellectual standing of Snouck Hurgronje as he did not acknowledge the contribution of Raden Aboe Bakar to his Mekeka, nor his hidden conversion to Islam as he appeared with the Islamic name of 'Abd al-Gaffār. ${ }^{18}$ Here, what constitutes the main concern is that his relationship with Raden Aboe Bakar mirrored his future vision of the Dutch policy on Islam in the colonial Indies.

Snouck Hurgronje, alias 'Abd al-Gaffār, commissioned Aboe Bakar to not only be his teacher in Malay, but also a key person who facilitated him to have direct contact with the Jawi. As well, Raden Aboe Bakar introduced him to his Morrocan teacher of origin, Sayyid 'Abd Allāh al-Zawāwī (1850-1924), who became Snouck Hurgronje's protector in Mecca. ${ }^{19}$ Therefore, a few months after his arrival in Jeddah on 24 August 1884 and staying at the consulate with Kruijt, Snouck Hurgronje moved to Aboe Bakar's home on 1 January 1885. This decision was of crucial importance to his mission. Here, Snouck Hurgronje began to be personally instructed in Islamic faith and then, on 16 January 1885 --under the witness of two Turkish officials-- converted to Islam. ${ }^{20}$ Consequently, it was from Aboe Bakar's home that the door opened for

${ }^{17}$ It is important to explain here that the book, Mekka, by Snouck Hurgronje, was originally written in German, and consists of two volumes: Mekeka: Die Stadt un Ihre Herren (Leiden: Brill, 1888), and Mekka: Aus dem Heutigen Leben (mit Bilder-Atlas) (Leiden: Brill, 1889). Here, all references are made to its English edition translated by J.H. Monahan, Mekek in the Latter Part of the $19^{\text {th }}$ Century: Daily Life, Customs and Learning of the Moslem of the East-Indian-Archipelago (Leiden: Brill, 1931).

${ }^{18}$ Koningsveld, Snouck Hurgronje dan Islam, pp. 100-5; 160-6; Michael F. Laffan, "Raden Aboe Bakar: An Introductory Note Concerning Snouck Hurgronje's Informant in Jeddah (1884-1912)", Bijdragen tot de taal-, land- en volkenkunde, vol. 155, no. 4 (1999), pp. $517-42$.

${ }^{19}$ Laffan, Islamic Nationhood, p. 59.

${ }^{20}$ Koningsveld, Snouck Hurgronje dan Islam, pp. 119-21. 
Jajat Burhanudin

Snouck Hurgonje to enter the holy city, Mecca.

As is already known, the Jawi of Mecca contributed to the formation of Islamic discourse in the Indies. This proceeded alongside the institutionalization of ulama, with their pesantren, in establishing an Islamic body with legitimate authority in translating Islam to the Muslim communities. To the Jawi of Mecca, and the Indies pilgrims in general, Snouck Hurgronje held the opposite view to that of the Dutch authorities. For him, they were unworldly scribes and teachers, most of whom desired nothing more than to serve Allah in peace. As a result, suppression was neither wise nor even necessary. ${ }^{21}$

Snouck Hurgronje's views on the peaceful nature of Islam did not hinder him from being cautious of the political danger of Muslim fanaticism. In this regard, he pointed to pan-Islamism and local fanatics in the form of Sufi orders. ${ }^{22}$ It was here, he argued, that the ground for fear lay as the Muslims translated Islam into political doctrine and movements. ${ }^{23}$ In light of this threat from the political nature of Islam, Snouck Hurgronje strongly recommended the Dutch government take an immediate, even if needed, military action to restrain any space for the growth of political Islam in the Indies. Thus, while endorsing impartial policy towards Muslim religious life, he did not tolerate the cultivation of any political character of Islam. Regarding the crucial role of a network with Mecca, Snouck Hurgronje in the last pages of his Mekeka wrote:

No reader of the above can accept the opinion of many officials who see in all Hajjis fanatical enemies of the Government; ... For the moment one still finds among these Hajjis scattered over the countryside, inflammable material not to be underestimated; which can flame up should any rash man produce a spark. This inflammability is due to the fact that the interest of the Hajji's are usually contrary to those of the Government, whilst many have brought from Mekka pan-Islamic tendencies which can easily develop into fanaticism. Those who have been a little longer in Mekka have in part developed into esteemed Qur'an teachers, in part into warm members of tariqah which does much more to introduce Islamic ideals of that kind into the Archipelago than the movement of the pilgrims masses, for with these one can angle only in cloud waters, whereas the

${ }^{21}$ Harry J. Benda, Continuity and Change in Southeast Asia: Selected Journal Articles of Harry J. Benda (New Haven: Yale University, 1973), pp. 86-7.

${ }^{22}$ Hurgronje, Mekeka, p. 290.

${ }^{23}$ Benda, Continuity and Change, p. 85. For Snouck Hurgonje's arguments on this issue, see: C. Snouck Hurgronje, Nederland en de Islam, 2nd edition (Leiden: Brill, 1915), pp. 361-91; G.H. Bosquet and J. Schacht (eds.), Selected Works of C. Snouck Hurgronje (Leiden: Brill, 1957); Dijk, "Colonial Fear", pp. 55-64. 
others exercise a slow but steady influence upon the prevailing sentiments. These, much more important influence, are only indirect consequences of the Hajj but nevertheless, consequences, and it is perhaps to be regretted that in past time, and in regions which had not hitherto sent out pilgrims, one did nothing to direct the stream into other channels. ${ }^{24}$

The mission Snouck Hurgronje carried out in Mecca did not end with his knowing the Indies pilgrims, nor with identifying their political potential of fanaticism. As the above quotation reveals, Snouck Hurgronje stressed that some crucial efforts should be made in the Indies, to make sure that the "inflammable material" in the bajj did not transform into a rebellious spirit. Instead, he proposed, it had to be directed "into other channels".

As a matter of fact, Snouck Hurgronje was the first scholar to criticize the Dutch hajj-policy. For him, the title of hadji and the quasi-Arab dress did not deserve an official reorganization as the 1895 ordinance promulgated. Likewise, any restrictions on the bajj would only yield adverse results. ${ }^{25}$ His views on the hajj are one example of what is said to be a new orientation in the mode of encounter between Dutch colonialism and Islam in the Indies. ${ }^{26}$ Based on his broad knowledge of Islam and Muslim culture, Snouck Hurgronje laid down the foundations for improving relations between Dutch authorities and Indies Muslims, replacing the previous sentiment of hostility. With this, he launched a vision for future evolution of Indies society, providing them with the spirit of liberalism entrenched in nineteenth century Europe. ${ }^{27}$

In so doing, Snouck Hurgronje directed his main concerns to the leaders of the Indies whom he believed would be able to lead the communities to a certain point in which both the Indies communities and the Dutch coexisted. This vision manifested since Snouck Hurgronje began learning about Islam. To be more precise, it was in Mecca that Snouck Hurgronje came to view Islam differently from the way the Dutch authorities did. Instead of associating Islam with fanaticism, the enemy of "infidel" rule, and labeling Mecca as the centre of the anti-Dutch conspiracy, Snouck Hurgronje stressed the peaceful nature of Islam and

${ }^{24}$ Hurgronje, Mekeka, p. 290.

${ }^{25}$ C. Snouck Hurgronje, Verspreide Geschriften (Den Haag: Nijhoff, 1924), p. 175.

${ }^{26}$ Karel A. Steenbrink, Dutch Colonialism and Indonesian Islam: Contacts and Conflicts 1596-1950 (Amsterdam: Atlanta GA, 1993), p. 77.

${ }^{27}$ Benda, Continuity and Change, p. 85. 
Jajat Burhanudin

the Muslims of the Indies. ${ }^{28}$ In Mek.ka he states, "not the Hajjis, the adepts of mystic orders, the divine educated in Mekka are dangerous, fanatical etc.; all three together however represent the intellectual connection of the East-Indies with the metropolis of Islam, and thus have the right to a more than superficial observation on the part of the European administration". 29

Therefore, concerning the Jawi of Mecca --whose crucial importance in Islamic development in the Indies far exceeded the influence of the hajis-- Snouck Hurgronje paid great concern. In addition to encouraging the Dutch Government "to know what goes on in Mekka, what elements are exported from there every year", Snouck Hurgronje at the same time strongly suggested that "skilful handling" should be taken in the Indies, so that "these [the elements exported by the Jawi] can be won over to support the Government or at least made harmless". ${ }^{30}$

Here, again we come to the disputed political nuance of Snouck Hurgronje's work on Mecca. ${ }^{31}$ Reading the last pages of Mekeka, it is clear that Snouck Hurgronje did not limit his mission in Mecca to engage in only the study of Indies pilgrims related to pan-Islamism and Sufi orders. He went one step further as he stressed how the Dutch government should deal with the Indies, besides staying alert on what developed in the intellectual heart of Islam in Mecca. With this, Snouck Hurgronje began entering a new phase of his public life. He started directing his intellectual exercises in the framework of a Dutch colonial project on Islam and in turn the Muslim people in the Indies. And this then was evidenced as he was appointed to the position of Adviser for Native and Arab Affairs (1889-1906) for the Dutch colonial government, which was institutionalized in het Kantoor voor Inlandsche en Arabische Zaken. ${ }^{32}$

It was in this office that Snouck Hurgronje thoroughly engaged in the formulation of Dutch colonial policy on Islam. To handle this task, a man like Raden Aboe Bakar in Mecca was needed. And Snouck Hurgronje did it again, as he had Hasan Moestapa (1852-1940) --whom he met in Mecca-- assist his advisory duties in het Kantoor. Hasan Moestapa, and other names I will mention later, became key contacts who opened

${ }^{28}$ Ibid., pp. 86-7; Harry J. Benda, The Crescent and the Rising Sun: Indonesian Islam under the Japanese Occupation 1942-1945 (The Hague: van Hoeve, 1983), pp. 23-5.

${ }^{29}$ Hurgronje, Mekeka, p. 291.

${ }^{30}$ Ibid.

${ }^{31}$ Koningsveld, Snouck Hurgronje dan Islam, p. 67.

${ }^{32}$ H. Aqib Suminto, Politik Islam Hindia Belanda: het Kantoor voot Inlandsche Zaken, 1899-1942 (Jakarta: LP3ES, 1985), pp. 99-114. 
the door for Snouck Hurgronje to gain local knowledge of Islam. They held roles as native informants who provided Snouck Hurgronje with certain facilities to have access to the inner-side of Islam and Muslims' lives in the Indies. ${ }^{33}$

However, one point is important to note here. Both Raden Aboe Bakar and Hasan Moestapa came from native elite of regent families respectively from Pandeglang in Banten and penghulu of Garut in West Java. It was an initial stage of Snouck Hurgronje's grand strategy to take native aristocracy as the first social class to be drawn into the colonial orbit, while the ulama of pesantren --as the nucleus of the Jawi-remained the independent "other" and were outside the colonial system of knowledge. Instead, they experienced heightened consolidation as a different social class from the aristocracy. Now I will pay attention to how Snouck Hurgronje dealt with Islam and the Muslims in the Indies and the way he translated his knowledge on Islam into colonial policy.

\section{Colonizing Islam}

Snouck Hurgronje arrived in the Indies on 11 May 1889. It was about four years after his dealings with the Jawi of Mecca. After staying for some time in Buitenzorg, Snouck Hurgronje began his mission by getting to know Islam from Garut in West Java. Snouck Hurgronje arrived in the town on 18 July 1889. From there, he started his tour of West Java in order to directly observe the way in which the Indies Muslims performed their Islamic faith, and hence his theoretical knowledge of Islam enriched. ${ }^{34}$

It was from Garut that Snouck Hurgronje's window on local Islam opened. Hasan Moestapa, his key informant, helped Snouck Hurgronje to carry out his mission. In 1886, long before Snouck Hurgronje's arrival to the Indies, Hasan Moestapa had returned from Mecca as his father had stopped sending him financial support for his stay in Mecca..$^{35}$ Moestapa then became a leading 'alim of Garut and, therefore, had a crucial role in Snouck Hurgronje's mission to learn Islam in the area. Not only did Moestapa accompany Snouck Hurgronje on his journey to Java, but he

${ }^{33}$ Laffan, Islamic Nationhood, pp. 84-5.

${ }^{34}$ B.J. Boland and I. Farjon, Islam in Indonesia: a Bibliographical Survey 1600-1942 with post-1945 Addenda (Doordrecht: Foris Publication, 1983), p. 16.

${ }^{35} \mathrm{Ph}$. S. van Ronkel, "Aanteekeningen over Islam en Folklore in West- en Midden-Java: uit het Reisjournal van Dr. C. Snouck Hurgronje”, Bijdragen tot de Taal-, Land-en Volkenkunde, vol. 101 (1942), p. 315. 
Jajat Burhanudin

also enabled him to have direct contact with the Muslims of the area. This journey was recounted by Hasan Moestapa in his Gendingan, ${ }^{36}$ in which he said that Snouck Hurgronje picked him up, while he was an 'älim (kikijaianan), wandering far and wide (atrok-atrokan) around Java. He mentioned such areas as Ponorogo, Surakarta, Yogyakarta, Madiun, Magelang, and the coastal areas.

As Aboe Bakar had done in Mecca, Hasan Moestapa facilitated Snouck Hurgronje's efforts to make contact and communicate with the ulama of Java. Here, Moestapa provided Snouck Hurgronje with a list of ulama of West Java, with some information on their areas of concern, their heirs, their teachers, places of origin, and families. ${ }^{37}$ Moestapa also disclosed to Snouck Hurgronje --and they later directly observed-- how the ulama of Java transmitted their Islamic knowledge to their santris, the kitabs they used, and certain religious practices the Indies Muslims performed at certain times and events. ${ }^{38}$ These observations showed Snouck Hurgronje the ways in which Islam was transmitted from Mecca and penetrated the Indies, and thus determined the religious life of the Muslims. ${ }^{39}$

As a key informant, Moestapa's relationship with Snouck Hurgronje became close. On the recommendation of Snouck Hurgronje, ${ }^{40}$ Moestapa was appointed as the Chief-Penghulu of Kutaraja, Aceh, in 1893. He then departed to Aceh to serve the Dutch authorities who engaged in the war, providing them with local knowledge on Islam and the Acehnese, the subject the Dutch needed to grasp in their efforts to pacify the area. ${ }^{41}$ Moestapa did not meet Snouck Hurgronje, who had already left Aceh in 1892, but his role as a native informant continued. Besides this, he was the Chief-Penghulu who engaged in the religious and social affairs of the Muslims. Moestapa established contact with the Acehnese people,

${ }^{36}$ Its complete title is Gendingan Danding Sunda Birabi Katut Wirahmana (Sundanese Songs of Love in Rhym). This work is one of the most important works of Hasan Moestapa, containing mostly his mystical thought. See: Jajang Jahroni, "The Life and Mystical Thought of Haji Hasan Moestafa (1852-1930)", Master's Thesis (Leiden: Leiden University, 1999).

${ }^{37}$ Ronkel, "Aanteekeningen over Islam", p. 316.

${ }^{38}$ Ibid., pp. 317-39.

${ }^{39}$ Laffan, Islamic Nationhood, p. 84.

${ }^{40}$ Snouck Hurgronje's recommendation to Hasan Moestapa can be found in his letter of 26 October 1892 to the Governor of Aceh. See: E. Gobée and C. Adriaanse (eds.), Ambtelijke Adviezen van C. Snouck Hurgronje 1889-1936, vol. 1 (The Hague: Nijhoff, 1957), p. 31.

${ }^{41}$ Veer, Perang Aceh, pp. 226-7. 
including Teuku Umar, an ulebalang who, like himself, worked for the Dutch until his defection as he turned against the Dutch the following year. $^{42}$

From such native elite as Moestapa, Snouck Hurgronje attempted to direct the Indies Muslims to come under Dutch wings. And the life and career of Moestapa illustrated such colonized Muslims as Snouck Hurgronje created in the Indies. His appointment as the Chief-Penghulu of Kutaraja led him to enter the menak circle, serving the Dutch by handling the socio-religious affairs of the Muslims. After two years of serving in Aceh, and again with Snouck Hurgronje's recommendation, Moetapa took up the same position in Bandung in 1895, replacing the retired Raden Hadji Moehammad Nasir. In this capital city of Priangan, he became the Chief-Penghulu until 1918. Thereafter, he lived as a respected Sundanese menak, delving into writing and reviving Sundanese literature. ${ }^{43}$

To Snouck Hurgronje, Moestapa embodied the nature of Indies Muslims that had Islam as only one source that contributed to determining their socio-political and religious life. It must be stressed that the significance of Islam in the life of its believers and the way it developed into an established system constituted the core premises of Snouck Hurgronje's intellectual ideas. ${ }^{44}$ He came to consider --and then elaborated further by van Vollenhoven-- the crucial role of what he termed the adat-recht (adat law). Defined as "custom, usage, rule, proper behavior, and propriety", ${ }^{45}$ the adat formed a major contributory element in the life of Indies Muslims, more than the precept of Islamic law held as his predecessors in Delft, Keijzer and van den Berg, had assumed. ${ }^{46}$ To Snouck Hurgronje, Moestapa's strong emotional engagement in the Sundanese culture, the adat, was to be the foundation that played an important role in his being ready to collaborate with the Dutch, to be appointed as the Chief-Penghulu. ${ }^{47}$

${ }^{42}$ Ibid., pp. $244-5$.

${ }^{43}$ Nina H. Lubis, Kehidupan Kaum Ménak Priangan, 1800-1942 (Pusat Informasi Kebudayaan Sunda, 1998), pp. 289-92; Tini Kartini, Biografi dan Karya Pujangga Haji Hasan Mustafa (Pusat Pembinaan dan Pengembangan Bahasa, Departemen Pendidikan dan Kebudayaan, 1985).

${ }^{44}$ G.W.J. Drewes, "Snouck Hurgronje and the Study of Islam", Bijdragen tot de Taal-, Land-en Volkenkunde, vol. 113 (1957), p. 4.

${ }^{45}$ M.A. Jaspan, "In Quest of New Law: The Perplexity of Legal Syncretism in Indonesia", Comparative Studies in Society and History, vol. 7, no. 3 (1965), p. 252.

${ }^{46}$ Boland and Farjon, Islam in Indonesia, p. 20.

${ }^{47}$ Gobée and Adriaanse (eds.), Ambtelijke Adviezen, 1: 31. 
Jajat Burhanudin

Snouck Hurgonje's underscoring of adat, instead of Islamic precept, in the formation of Muslim life was established with his project of understanding the Acehnese, where the spirit of jihad was deeply rooted. He took a seven-month tour of duty in Aceh (July 1891 to February 1892) just after he finished his journey of Java. Again assisted by some local informants he had already met in Mecca, including Habīb 'Abd alRaḥmān al-Z̄āhir, ${ }^{48}$ Snouck Hurgronje engaged in trying to comprehend the inner-side of Acehnese Muslims. The Meccan experience played a crucial role in making Snouck Hurgronje's mission in Aceh successful. For example, he was able to attract a hostile 'alim of Aceh and lead him to collaborate with the Dutch. ${ }^{49}$ As a result, in addition to being able to "provide intelligent direction to the military sorties" command of J.B. van Heutsz (1851-1924), the future Governor General and "Pacifier of Aceh", Snouck Hurgronje came to the next stage of his intellectual achievement. From his tour of duty in Aceh, and of course with information from his native informants, he presented an impressive report to the colonial government, who then ordered him to rewrite and extend the first two parts into a book, which later appeared in two great volumes as The Acehnese (1906)..$^{51}$ On the other hand, the third and fourth parts of his report, which contained an extensive discussion on the war and policy recommendation, remained secret for over half a century. ${ }^{52}$

The Acehnese, like Mekeka, was a result of Snouck Hurgonje's project of knowing Islam in the framework of the colonial agenda. In The Acehnese Snouck Hurgronje provided us with an extensive discussion on various subjects concerning the Acehnese. The first volume was dedicated to delineating the socio-political and cultural life of the Acehnese. He dealt with, for instance, the issues on the structure of the people, their forms of government and administration of justice, and their mode of social life in which the adat held a regulatory function. In the second volume, he focused on intellectual tradition and religious life --on Islamic learning and science, literature, and religious belief and practices of the Acehnese.

${ }^{48}$ Anthony Reid, "Habib Abdur-Rahman az-Zahir (1833--1896)", Indonesia, vol. 13 (1972), pp. 36-59.

${ }^{49}$ Koningsveld, Snouck Hurgronje dan Islam, pp. 82-3.

${ }^{50}$ Anthony Reid, The Contest for North Sumatra: Atjeh, the Netherlands, and Britain, 1858-1898 (Kuala Lumpur: University of Malaya Press, 1969), p. 278.

${ }^{51}$ Here I refer to the English edition, The Acehnese (1906) translated by O'Sullivan from its Dutch original version, De Atjehers (1893-1894).

${ }^{52}$ W.F. Wertheim, "Counter-Insurgency Research at the Turn of the Century: Snouck Hurgronje and the Acheh War", Sociologische Gids, vol. 19 (1972), p. 323. 
As in Java, Snouck Hurgronje again observed how little the Islamic doctrine the Acehnese searched for in Mecca affected daily life in the homeland. This point led Snouck Hurgronje to come to what I already noted as the supremacy of adat above shari'ah. In Aceh, the area in which "the doctrine of jihad has been for centuries more deeply rooted here than in other parts of the archipelago", ${ }^{53}$ Islam had only minimal influence on the regulation of the social and political affairs of the Acehnese people. To him, despite that fact that the ulama were "trained in the doctrine that the adat (custom law) and bukom (religious law) should take their places side by side in a good Mohammedan country", "but in such a way that every great portion of their lives is governed by adat, and only a small part by bukom" ${ }^{54}$ Therefore, Islam would not be able to exercise influence on the regulation of Muslims' life. In this regard, Snouck Hurgronje wrote:

Islam has never even at the zenith of her power and glory succeeded in subjecting to the control of her law in the government, the administration of justice and the trade relations of her adherents or in causing this law to keep pace in its development with the requirements of every day life. As the time went on, it became more and more clear that the teaching of Islam could in fact only hold its own in the sphere of dogma and ritual, of domestic life and of the relation of the followers of the Prophet with those of other creeds; all other matters were emancipated from its control without the slightest influence or pressure from without. ${ }^{55}$

Hence, it is evident from The Acehnese that Snouck Hurgronje was firmly of the opinion that adat and Islam were two distinct and separate domains, in terms of cultural, social and political spheres. The adatIslam relationship expressed tension and conflict, as was evidenced in the then prevailing social and political relations between the uleebalang and the ulama, the holders of adat and shari'ah respectively. This distinction, which then came to be the legacy of orientalist studies on Islam in Southeast Asia, ${ }^{56}$ had strong political ramifications. The colonial project of Islam, of which Snouck Hurgronje was in charge, was based on the assumed existence of these two separate entities in the Indies Muslims. Snouck Hurgronje then recommended the colonial government take the

${ }^{53}$ C. Snouck Hurgronje, The Achehnese, vol. 2, trans. by A.W.S. O'Sullivan (Leiden: Brill, 1906), p. 351.

${ }^{54}$ Ibid., 1: 14.

${ }^{55}$ Hurgronje, The Achebnese, 2: 338-9.

${ }^{56}$ William R. Roff, "Islam Obscured? Some Reflections on Studies of Islam \& Society in Southeast Asia”, Archipel, vol. 29, no. 1 (1985), p. 10. 
Jajat Burhanudin

side of uleebalang party, holding them in esteem so that they would accept the authority of the Dutch. As for the ulama of dayah, he opined that an active war should be waged to crush them heavily into the remotest corners of the interior of Aceh. ${ }^{57}$ Snouck Hurgronje's recommendation earned widespread support. The Dutch military expedition, under the command of van Heutsz, succeeded. Starting with the Pidie expedition of 1898, they then subdued other areas of Aceh. The uleebalang signed a 'short declaration' (korte verklaring), drafted by Snouck Hurgronje, pledging that they were subjects to the Netherlands Indies and would obey all its instructions. ${ }^{58}$

On the basis of his successful handling of Acehnese affairs, as well as in Java, Snouck Hurgronje directed the Islam policy which sought to draw the native elites, the adat holders, into the colonial corner. This was also based on his argument of the changeable characters of adat, that "it never remains stationary", ${ }^{9}$ so that the adat holders in the long run would easily adapt to the new mode of life the Dutch introduced to the Indies. Here, the experiences of penghulu in Java and uleebalang in Aceh appeared to be the foundation of the colonial project on Islam he proposed. Both uleebalang and penghulu enjoyed living under the Dutch, through which the Indies communities were expected in turn to follow, coming under colonial authority. Snouck Hurgronje established his vision of the future Indies, that would become a "westernized Indonesia", which galvanized in his project of "emancipation" in the early twentieth century.

In the discussion which follows, I will pay attention to the way the above standpoint of Snouck Hurgonje on the supremacy of adat operated, as was expressed in the making of penghulu became increasingly part of the priyayi circle that allied with the Dutch. Together with Said Oesman of the Arab community, the penghulu became strongly colonized, as the Dutch partner and collaborator, who voiced Islamic discourses in accord with the colonial interest.

\section{Colonial Partner and Collaborator: the Penghulu and Said Oesman of the Arabs}

On 19 January 1882, King Willem III issued Royal Decree No. 24 to establish the so-called "Priests' courts" (Priesterraad) in Java and Madura. This decree, formulated in the framework of restructuring the

${ }^{57}$ Wertheim, “Counter-Insurgency Research”, p. 324.

${ }^{58}$ Reid, The contest for North Sumatra, pp. 278-80.

${ }^{59}$ Hurgronje, The Achebnese, 1: 10. 
Islamic legal body of the areas, stipulated the formation of priesterraad at the level of regency (kabupaten) alongside the primary court of justice (landraad), which had already been founded in the closing time of the VOC period in the Indies. ${ }^{60}$ Here in the priesterraad the penghulu presided, with the assistance of three Islamic experts, funded by the Office for Native and Arab Affairs. This office defined its legal authority as relating to cases of marriage, divorce, custody, inheritance, religious alms and grants as well as donations. ${ }^{61}$

With this newly-created office, the pengbulu, who had been responsible for the Islamic affairs of pre-colonial states in the archipelago, transformed into being a part of the colonial legal system. Consequently, they served the Dutch as government officials (ambtenaren), and mediated between the colonial administration and its Muslim subjects. Although entrenched in pesantren tradition, having mastered the kitabs of Islamic law, the penghulu nevertheless became part of and were closely associated with the native bureaucracy (priyayi) circle. ${ }^{62}$ Moreover, caused in part by their dependence on the Dutch Resident who since 1917 paid their salaries, and the regent (bupati) who played an essential role in their nomination to the position, the pengbulu became subordinate to their Dutch and native masters. ${ }^{63}$ Therefore, instead of articulating Muslims' interest, the penghulu engaged in voicing and in turn imposing colonial order.

It was with the penghulu, especially Hasan Mostapa, that Snouck Hurgronje came into contact as he started his advisory duties in the Indies. Yet, concerning this particular issue of penghulu, the role of Karel Frederick Holle (1826-1896), who had already worked for Islamic affairs in the Indies before the arrival of Snouck Hurgronje is of crucial importance to note here briefly. And Snouck Hurgronje followed Holle, in that he attempted to systematically draw the penghulus away from the Islamic and the Arabic influence.

As is known, Holle was the one behind the language policy which urged the penghulu of West Java to use the Latin script, instead of the Arabic one, in their writings. Having delved into the lives of the Sundanese people, more in particular through his strong relationship

${ }^{60}$ Muhammad Hisyam, Canght between Three Fires: The Javanese Pangulu under the Dutch Colonial Administration (Jakarta: INIS, 2001), pp. 47-52.

${ }^{61}$ Ibid., pp. 59-60. See also: Karel A. Steenbrink, Beberapa Aspek tentang Islam di Indonesia Abad ke-19 (Jakarta: Bulan Bintang, 1984), pp. 200-1.

${ }^{62}$ Hisyam, Caught between Three Fires, pp. 65-7.

${ }^{63}$ Ibid., p. 68. 
Jajat Burhanudin

with Muhammad Moesa, Chief-Penghulu of Garut, Holle became deeply involved in Islamic affairs. And this, as well as his great concerns for the Sundanese, intensified as he was in 1871 appointed to the post of Honorary Adviser on Native Affairs to the Colonial Government. From this office, Holle began working seriously on Islam with Moesa as his key informant. He launched a project aimed at diminishing Islamic impacts on the Indies Muslims, in particular the Sundanese.

Therefore, while reviving Sundanese culture, Holle attempted to draw the Priangan elites (kaum menak) away from Islam and any kind of Arabo-Islamic elements. He recommended the penghulus use Latin script to replace the widely used Arabic script, which was regarded as having produced the hostile and Islamic impacts from Mecca on the Indies Muslims. ${ }^{64} \mathrm{He}$ also suggested the government not tolerate the hajj influence, which included such measures as, for instance, not appointing returned Hadjis and ulama from Mecca to higher governmental posts. ${ }^{65}$

Holle essentially established the foundations of what came to be the Dutch colonial policy on Islam. He started and succeeded in drawing the Priangan elite of penghulus into the circle of kaum menak and, in turn, the colonial domain. ${ }^{66}$ Here, Moesa is a good example to illustrate. He came from the menak family. His father, Raden Rangga Soerjadikoesoemah, was a patib (vice regent) of Limbangan. Due to the expansion of santri culture during this period, he had pesantren learning as his first education. Like other santri, Moesa went to Mecca for the bajj when he was still a young boy. With these menak and santri backgrounds, Moesa became a potential native leader the Dutch searched for to fill the religious office of penghulu they had just created. Thus, in 1864 Moesa was appointed as the Chief-Penghulu of Limbangan. Hence, he not only enjoyed his career that provided an annual salary of $f 900$ plus an additional $f 750$, but he also started enjoying the menak lifestyle. He lived as a wealthy man in a beautiful house, and had an extensive network with both menak and Dutch communities.

${ }^{64}$ Mikihiro Moriyama, "A New Spirit: Sundanese Publishing and the Changing Configuration of Writing in Nineteenth Century West Java", Ph.D. Thesis (Leiden University, 2003), p. 6. It should be stated here that the script has in fact been taken as the socio-cultural and political identity of certain communities. For the discussion on the sociological and historical meanings of the script, see also: Kees van Dijk, "From Head to Toe: Dress, Script, Culture and Identity", presented at the International Workshop on Southeast Asian Studies: Script as Identity Marker in Southeast Asia (Jakarta, 2004).

${ }^{65}$ Steenbrink, Dutch Colonialism, p. 79; Laffan, Islamic Nationhood, p. 82.

${ }^{66}$ Lubis, Kebidupan Kaum Ménak. 
Indeed, the priyayi characters of penghulu can be observed. Besides their lifestyles, as in the case of Moehammad Moesa, the penghulu had their own perspectives and articulation of Islam. Here, I will pay attention to the works of Moestapa. As his biography reveals, ${ }^{67}$ Moestapa had experience of pesantren Islamic learning. Moreover, he spent many years learning Islam in Mecca. Therefore, he undoubtedly had an extensive knowledge of Islam, and due in part to this cause, they became wellknown 'alim before being appointed to the office of the Chief-Penghulu of Kutaradja following his being key native informant of Snouck Hurgronje in his duty in the Indies. Reading, for instance, Jahroni's study on his Gendingan, one of his works containing mystical endeavours, it is clear that Moestapa was familiar with Islamic intellectual tradition. ${ }^{68}$ In the Gendingan, he formulated his mystical teaching with reference to the Sufi works by such leading Sufi ulama as ibn 'Arabī and al-Jìlī as well as al-Gazālī. References to the Islamic tradition and doctrine also appeared in his collected works entitled Aji Wiwitan. ${ }^{69}$

Moestapa was not the only penghulu with such a model. To some extent the same also applied to other penghulus of Java, Mas Hadji Ichsan (18775/77-1929) and Muhammad Adnan (1889-1969), the pengbulus of Temanggung and Solo in Central Java respectively. ${ }^{70}$ Like Moestapa, both penghulus had a strong educational background in the pesantren. Hadji Ichsan studied Islam in a pesantren in Kebumen, Central Java, while Adnan was once a student of a highly-esteemed pesantren in Solo, Jamsaren. Both continued to learn Islam in Mecca. Therefore, it can be deduced that the penghulu had a similar intellectual journey to, and read the same kitabs as the ulama of the pesantren. Based on biographical stories of certain pengbulus, Pijper provided us with some evidence of penghulus' vast reading of well-known kitabs, showing that their appointment to the offices did not hinder them from being the ulama. ${ }^{71}$

Nevertheless, reading the works of Moestapa, it appears that they departed from the kitabs circulated within and used by the ulama of

${ }^{67}$ Nina H. Lubis, "Religious Thought and Practices of the Kaum Menak: Strengthening Traditional Power", Studia Islamika, vol. 10, no. 2 (2003), pp. 1-30.

${ }^{68}$ Jahroni, "The Life and Mystical Thought”, pp. 63-97.

${ }^{69}$ Kartini, Biografi, pp. 43-124; A. Rosidi, "Menjejaki Karya-Karya Haji Hasan Mustapa", in Warisan Intelektual Islam Indonesia: Telaah atas Karya-Karya Klasik, ed. by Ahmad Rifa'i Hasan (Bandung: Mizan, 1987).

${ }^{70}$ Hisyam, Caught between Three Fires, pp. 261-89.

${ }^{71}$ G.F. Pijper, Beberapa Studi tentang Sejarah Islam di Indonesia, 1900-1950 Jakarta: UI-Press, 1984), pp. 93-100. 
Jajat Burhanudin

pesantrens. Despite the strength of his Islamic messages, as in his Gendingan and some chapters of Aji Winitan, Moestapa tended to express his teachings and ideas in the writing format of the deeply-rooted in the Javanized-Sundanese literature, suluk. Derived from the Arabic sulük, meaning "to follow or travel along a road", ${ }^{72}$ suluk has become a genre of Javanese literature that points to complex texts that essentially contain Sufism and convey it allusively and often symbolically. ${ }^{73}$ It was this form of suluk that Moestapa employed for conveying his intellectual ideas, more precisely danding and guguritan, the Sundanese format of Javanese suluk literature tradition. ${ }^{74}$

Here, the mentioned Gendingan of Moestapa is a good example. As can be seen from its contents, the Gendingan presents Moestapa's profound knowledge of Sufism. This work deals with, among others, the relationship between the form (labir) and essence (batin), the Sufi doctrine of seven stages (martabat tujub), the principles and method of Sufism, and his opposition to religious formalism. ${ }^{75}$ Examining these subjects, as in the case of suluk, ${ }^{76}$ there existed the discourses familiar with the pesantren tradition of learning. Yet, it must be stressed, this writing style of Gendingan took form of canto ( with and even belonged to the menak culture. ${ }^{77}$ Such Sundanese forms of cantos as asmarandana, dandanggula, kinanti, and maskumambang appeared to be the main form of rendition Moestapa used in his Gendingan. ${ }^{78}$ And all of those mentioned forms of rendition existed increasingly out of pesantren tradition. The pesantren on the contrary became a more firmly established institution of Islamic learning, and the ulama with their students (santris) became more concerned with reading the Arabic kitabs.

It was due in part to the colonial project of Islam that Moestapa became increasingly less associated with pesantren domain, and as a consequence, his Gendingan became the least publicly known work. It evolved into becoming almost exclusively a study subject of a small

${ }^{72}$ Hans Wehr, A Dictionary of Modern Written Arabic, ed. by J. Milton Cowan (Beirut: Librairie du Liban, 1974), pp. 423-4.

${ }^{73}$ Nancy K. Florida, Writing the Past, Inscribing the Future: the History of Prophecy in Colonial Java (Durham: Duke University Press, 1995), pp. 259-60, 212-3.

${ }^{74}$ Rosidi, "Menjejaki Karya-Karya Haji Hasan Mustapa”, pp. 80, 83-6.

${ }^{75}$ Jahroni, "The Life and Mystical Thought”, p. 61.

${ }^{76}$ Simuh, Mistik Islam Kejawen Raden Ngabehi Ranggawarsita: Suatu Studi terhadap Serat Wirid Hidayat Jati (Yogyakarta: IAIN Sunan Kalijaga, 1983), p. 3.

${ }^{77}$ Lubis, Kehidupan Kaum Ménak, p. 176.

${ }^{78}$ Kartini, Biografi, pp. 105-6. 
circle, Galih Pakuan, which proclaims to be the followers of Moestapa's mystical teachings. ${ }^{79}$ Considering his use of the Arabic script, Moestapa basically still linked up with the pesantren tradition, be it in a modest way. This contrasts with the works of Moesa. Reading Wawacan Panji Wulung, one of his most widely read and admired works, shows that Moesa radically departed from the pesantren tradition in which he had experience as well. In addition to using the Latin script, as Holle had strongly urged, it also presented Moesa's struggle for self-discovery of being a modern Sundanese author. ${ }^{80}$

As a result, Moestapa, like Moesa, appeared more as a Sundanese author on the Sundanese culture and literature. His work on the Sundanese subject, Bab Adat-Adat Urang Sunda jeung Priangan Liana ti Eta, was the most widely celebrated one. Dedicated to his patron, Snouck Hurgronje, ${ }^{81}$ this work was therefore the only one that went to the Dutch Government-owned publishing house, Kantor Tjitak Kandjeng Goepernemen, in Batavia. Since its first publication in 1913, then translated into Dutch by R.A. Kern in 1946, it has enjoyed popularity and attracted great attention. In 1985, its Indonesian translation by Maryati H. Sastrawijaya began to appear. Hence, it is not a surprise that Moestapa came into public knowledge more with his work on the Sundanese while his writings on Islam --notably in the Gendingan-- led him to be reputedly called an "eccentric "älim" (ulama mabiwal), who invited debates and controversies. ${ }^{82}$

In the increasingly colonized Indies of the nineteenth century, the cases of Moesa and Moestapa were not unique. The Dutch scholarly and notably philological studies, which arose alongside colonial political interest, were more interested to discover what they referred to as the authentic and original culture of the Indies. Javanology, a Dutch centre for research on the Javanese, which included training for civil servants in Java, directed its activities mainly to the study of the Javanese language

${ }^{79}$ Jahroni, "The Life and Mystical Thought”, p. 57; Wendy Solomon, “Text and Personality: Ajip Rosidi in Search of Haji Hasan Mustapa”, Indonesia Circle, vol. 14, no. 41 (1986), p. 14.

${ }^{80}$ Moriyama, “A New Spirit”, pp. 105-13.

${ }^{81}$ In his letter to Snouck Hurgronje, dated 12 February 1911, Moestapa wrote that he promised writing, at Snouck Hurgronje's behest, on the subjects concerning the tradition and customs (adat) of the Sundanese community (Leiden Library collection, Cod.Or. 8952). Moestapa completed his work one year later, and he delivered its complete draft to Hazeu to publish.

${ }^{82}$ Solomon, "Text and Personality", p. 14. 
Jajat Burhanudin

and literature that predated to the pre-Islamic period, ${ }^{83}$ in which the "Old Javanese Heartland" existed and therefore was to be the subject of studies. ${ }^{84}$

Moreover, and most likely entailed in anti-Islamic sentiment of Orientalism ${ }^{85}$ the Dutch scholars tended to put the Islamic texts under the heading of presumably original Javanese. One leading Dutch philologist, Th. Pigeaud, ${ }^{86}$ was therefore in favour of naming suluk literature as "Javanese mystical songs". He not only ignored the Islamic element of suluk, but also credited Islam as having created a historical rupture in the Javanese literature tradition. To him, the renaissance of Javanese culture in the nineteenth century was to be signified as "the turning of the attention of Javanese scholars from Islamic texts to Old Javanese kakawins". ${ }^{87}$ In this respect, Pigeaud was to some extent like Snouck Hurgronje who asked Moestapa to write and then helped to publish his Bab Adat-Adat Urang Sunda, but left his Gendingan out of any scholarly discussions.

The above trend of Dutch scholarly studies can also be observed in the Malay area of Sumatra. Here we come to Pulau Penyengat, the leading centre of Islam and Malay culture of the nineteenth century RiauLingga kingdom. ${ }^{88}$ Like their fellows in Javanology, the Dutch authorities and scholars of Malay, centred in Tanjung Pinang, also concentrated on the cultivation of the original Malay language and literature. To the works of Raja Ali Haji ( \pm 1809-1872), for instance, the most leading scholars of Riau-Lingga royal family, they mostly paid attention to those containing the subjects they needed in the colonial framework. Roorda van Eysinga (1807-74), the man behind the founding of Indologist

${ }^{83}$ Kenji Tsuchiya, "Javanology and the Age of Ranggawarsita: An Introduction to the Nineteenth Century Javanese Culture", in Reading Southeast Asia, ed. by Audrey Kahin (Ithaca: Southeast Asia Program Cornell University, 1990), pp. 89-91; E.M. Uhlenbeck, A Critical Survey of Studies on the Languages of Java and Madura ('s-Gravenhage: Nijhoff, 1964).

${ }^{84}$ Florida, Writing the Past, p. 26.

${ }^{85}$ Edward Said, Orientalism: Western Conceptions of the Orient, revised edition (London: Penguin, 1995).

${ }^{86}$ G. Th. Pigeaud, Literature of Java, vol. 1 (The Hague: Martinus Nijhoff, 1967), p. 85 .

${ }^{87}$ Ibid., 1: 236.

${ }^{88}$ Virginia Matheson, "Pulau Penyengat: Nineteenth Century Islamic Centre of Riau”, Archipel, vol. 37, no. 1 (1989), pp. 153-72; Alimuddin Hassan Palawa, "The Penyengat School: A Review of the Intellectual Tradition in the Malay-Riau Kingdom”, Studia Islamika, vol. 10, no. 3 (2003), pp. 97-121. 
training in Delft in 1842 and then Leiden in 1864, ${ }^{89}$ published his Syair Abdul Muluk in the Dutch journal Tijdschrift voor Nederlandsch Indie (1847: 285-526), while Eliza Netscher, the Dutch resident in Tanjung Pinang (1861-1870), published his well-known Gurindam Dua Belas in Tijdschrift van het Bataviaasch Genootschap (1854: 108-270). The same was also true with his Malay grammar treatise, Bustanul Katibin. This work was lithographed in 1857 under the support of Von de Wall (1807-73), his German friend who was in charge of compiling a Malay-Dutch dictionary to whom Raja Ali Haji served as informant and assistant. ${ }^{90}$

On the contrary, as in the case of Snouck Hurgronje to Moestapa, the mentioned Dutch scholars and authorities kept aloof from taking Raja Ali Haji's works with substantial Islamic contents onto the stage of intellectual debate. As a result, his Thamara al-Mubimma and Intizām waza'if al-Malik, in which he launched his strong will and agenda for the restoration of Malay kerajaan politics, ${ }^{91}$ remained out of colonial knowledge. Raja Ali Haji himself did not mention his two cited works in his friendship correspondence with Von de Wall, apparently realizing that they would not --and in fact did not_-attract Dutch scholarly scrutiny. ${ }^{92}$ Here, the cited works of Raja Ali Haji had the same fate as Moestapa's Gendingan. And, also like Gendingan, both Thamara and Intizām, together with his masterpiece Tubfa al-Nafis, were the leading, but then neglected, works of Raja Ali Haji on Islam and Malay kingship. Especially in Thamara, he provided Riau-Lingga rulers with Islamic political guidance which is reminiscent of the Taju us-Salatin in seventeenth century Aceh, and of course Nașị̆a al-Mulük of al-Gazālī, from which his Thamara was mainly sourced. ${ }^{93}$

With all those mentioned facts, it is clear that the Dutch authorities contributed to directing the penghulus, and native aristocracy in general, to follow the course that they had created at their own behest. As a

\section{${ }^{89}$ Boland and Farjon, Islam in Indonesia, p. 9.}

${ }^{90}$ Jan van der Putten and Al-Azhar (eds.), Di Dalam Berkekalan Persahabatan: Letters from Raja Ali Haji (Leiden: Department of Languages and Cultures of Southeast Asia and Oceania Leiden University, 1995), pp. 5-13.

${ }^{91}$ Jajat Burhanudin (ed.), Ulama Perempuan Indonesia (Jakarta: Gramedia-PPIM UIN Jakarta, 2002), pp. 164-7.

92 Putten and Al-Azhar (eds.), Di Dalam Berkekalan Persababatan, p. 18.

${ }^{93}$ Barbara Watson Andaya and Virgina Matheson, "Islamic Thought and Malay Tradition: the Writings of Raja Ali Haji of Riau (ca. 1809-ca. 1870)", in Perceptions of the Past in Southeast Asia, ed. by David Marr and Anthony Reid (Singapore: Heinemann Educational Books, 1979), p. 116. 
Jajat Burhanudin

result, the penghulus became increasingly engaged in religious and cultural activities directed by their Dutch masters, which in turn gave them, like uleebalang in Aceh, ${ }^{94}$ a sort of vested interest in stability under the Dutch.

Yet, despite their increasing engagement in priyayi lifestyle, some of the pengbulus still stayed within and paid high respect to the ulama. They maintained the prescribed obedience to their teachers in the pesantren learning they had experienced. Of course, as government officers, the penghulus were occasionally ordered to ask the ulama not to be involved in any kinds of activities that might provoke the rise of a rebellion and disorder ${ }^{95}$ as a circular of 1889 by Haji Soelaiman, the penghulu of Cianjur, testified. ${ }^{96}$ Nonetheless, in doing so, the penghulus still showed great respect, persuading them in such a gracious manner. In the Banten revolt of 1888, in which the ulama were involved, the penghulus favoured making a cautious response. Rather than accusing the ulama, they paid more attention to the need of maintaining order within the Muslims. Instead, vehement criticism and even accusation came from a well-known Hadrami 'álim, Said Oesman (1822-1913). The Dutch included this 'álim, besides the penghulu, in the project of colonizing Islam the Indies.

\section{E. Said Oesman and the Arabs}

Born in Pekojan, an Arab ghetto the Dutch created in Batavia, Said Oesman (Sayyid 'Uthmān ibn 'Abd Allāh ibn 'Aqūl ibn Yahyyā al-'Alawī) grew up in a religiously educated family. Al-Mișrī, his grandfather, was a respected 'alim in Batavia and took care of the young Oesman when his father returned to Mecca. When al-Mișrī died in 1847, Said Oesman, then eighteen years old, went to Arabia to continue his studies. 'Abd alGānī Bīmā and Aḥmad Zainī Daḥlān were among his teachers in Mecca. He also travelled to other countries in the Middle East, North Africa

${ }^{94}$ Reid, The contest for North Sumatra, p. 278.

${ }^{95}$ Sartono Kartodirdjo, Elite dalam Perspektif Sejarah (Lembaga Penelitian, Pendidikan dan Penerangan Ekonomi dan Sosial, 1983), p. 78.

${ }^{96}$ This circular was written by Haji Soelaiman following the Banten revolt of 1888, in which the ulama and a small number of penghulus were involved and then arrested; Kartodirdjo, The Peasant Revolt, p. 344. Therefore, this circular contains six points, asking the ulama to obey the colonial order, to accept the colonial authority, to avoid teaching false doctrines to the santris, to make the community aware of paying tax to the government, to practice religious obligations, and to thank God for the blessing of living under the Dutch Colonial Government. This circular can be found in Perpustakaan Nasional, Jakarta (104 A KFH 1/7); see also: Hisyam, Caught between Three Fires, pp. 90-2. 
and Istanbul, partly in order to study with well-known ulama. He then returned to Batavia in 1862, and began establishing a printing press. ${ }^{97}$

Said Oesman's reputation started as he came to the colonial knowledge in 1885. His writings on the Naqshbandiyya Sufi order, al-Nasīha al-Aniqa li al-Mutallabisin bi al-Tariqa, (Elegant Advice for Adherents of the Tariqa, Batavia 1883), was employed by the Dutch authorities, in particular Holle, in handling the Cianjur affairs of 1885. This anti-Naqshbandiyya work of Said Oesman was taken to be the foundation of Holle's argument on the potential danger of the tarekat in Cianjur around 1885, of which native aristocracies of the region became active members. ${ }^{98}$ There is no need here to give a detailed explanation of the affairs. What is important to stress is that the Cianjur affairs became a moment for future collaboration of Said Oesman with the Dutch colonial government.

It was Snouck Hurgronje who then became the patron of Said Oesman. Snouck Hurgronje might have already known him through Van der Chijs in the Hijāz, with whom Said Oesman made regular contact. As the Dutch were paying more attention to the growing Hadrami community in the Indies, ${ }^{99}$ such leading Hadrami 'alim as Said Oesman showed potential to become the leaders that Snouck Hurgronje was searching for. In 1886 he already praised Said Oesman as an Arab ally for the Indies Government'. ${ }^{100}$ Equally, Said Oesman realized that Snouck Hurgronje was a potential patron. He therefore showed his willingness to serve the Dutch in a letter he sent to Snouck Hurgronje. As a result, he was recommended for a governmental post not long after Snouck Hurgronje's arrival in Batavia in 1889. After two years of service, on 20 June 1891, Said Oesman was then appointed as the Honorary Adviser on Arab Affairs. ${ }^{101}$

${ }^{97}$ Azyumardi Azra, "A Hadrami Religious Scholar in Indonesia: Sayyid "Uthmān", in Hadrami Traders, Scholars and Statements in the Ocean, 1750s-1960s, ed. by Ulrike Freitag and William G. Clarence-Smith (Leiden: Brill, 1997), pp. 250-2; Laffan, Islamic Nationhood, p. 85.

${ }^{98}$ Steenbrink, Dutch Colonialism, pp. 80-4; Kartodirdjo, The Peasant Revolt, pp. $161-2$.

${ }^{99}$ Huub de Jong, "Dutch Colonial Policy Pertaining to Hadrami Imigrants", in Hadrami Traders, Scholars and Statements in the Ocean, 1750s-1960s, ed. by Ulrike Freitag and William G. Clarence-Smith (Leiden: Brill, 1997), pp. 94-111.

${ }^{100}$ It was a title of Snouck Hurgronje's writing in the Nieuwe Rotterdamsche Courant (14-16 October 1886), in which he wrote that "an Arab like Othmān ibn Jahja is more valuable than a lot of wine-drinking and 'free-thinking' bupatis"; quoted from: Laffan, Islamic Nationhood, p. 87.

${ }^{101}$ Ibid. 
Jajat Burhanudin

Hence, Said Oesman dedicated his life and intellectual capacity to the Dutch Indies Government, adding to the accumulated knowledge on Islam that the Dutch had gained from the penghulu. As a Hadrami, the political standing of Said Oesman was not without strong ground. He represented common knowledge on the Hadrami community in the Indies, who were "said to be indifferent to political matters, ignoring the Dutch oppression of indigenous Muslims as long as their own interests were not in jeopardy". ${ }^{102}$ Said Oesman, just like the penghulu, emerged as a leading religious advocate who voiced rust en orde the Dutch imposed in the Indies. This role in fact corresponded with his own spirit of reform which in part came from his ancestors' land, where religious reformism formed a leading intellectual discourse in nineteenth century Hadramaut. ${ }^{103}$ As a result, the reform spirit he voiced, concerning mainly his opposition to local beliefs and practices, as well as tarekat, ${ }^{104}$ loomed as an effective campaign for the Dutch colonial agenda. This became evident as the Dutch showed willingness, as Snouck Hurgronje proposed, to provide subsidies for the production and distribution of the works he wrote pertinent to the Dutch colonial policy on Islam in the Indies. ${ }^{105}$

In such a political setting, his Minhäj al-Istiqäma fí al-Din bi al-Saläma (Batavia, 1889-90) can hardly be viewed out of the sphere of colonial politics. In addition to listing around twenty-two examples of strongly prohibited bid'a practices by the Muslims, Said Oesman at the same time launched strong and vehement criticism against the ulama who were involved in the call for jihad, pointing especially to the Banten revolt of 1888. He signified the Banten jihad as gurur (delusion) to the true teaching of Islam, and accused the ulama of following the devil. ${ }^{106}$ In this regard, Said Oesman stood behind Moesa and Holle, blaming the ulama of pesantren and the followers of tarekat (Naqshbandiyya and Qādiriyya) for their being "foolish" for backing the mentioned revolt of Banten. Moreover, he even credited them as having practiced local innovation

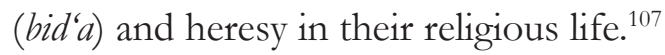

${ }^{102}$ Azra, "A Hadrami Religious Scholar", p. 253.

${ }^{103}$ Alexander Knysh, "The Cult of Saint and Religious Reformism in Hadramaut", in Hadrami Traders, Scholars and Statements in the Ocean, 1750s-1960s (Leiden: Brill, 1997), pp. 199-216.

104 Azra, "A Hadrami Religious Scholar", pp. 256-63.

105 Sumit Kumar Mandal, "Finding Their Place: A History of the Arabs in Java under Dutch Rule, 1800-1924”, Ph.D. Dissertation (Columbia University, 1994), p. 127.

106 Azra, "A Hadrami Religious Scholar", p. 254.

${ }^{107}$ Ibid., pp. 260-1; Laffan, Islamic Nationbood, pp. 87-8. 
Hence, the political standing of Said Oesman towards the Dutch was established. He was a loyal Hadrami 'älim who dedicated himself, as Snouck Hurgronje had expected, to giving religious legitimacy to the Dutch colonial powers of the Indies, leading his patron then to create in 1897 a pseudo-official post in which Said Oesman was in charge as the Muftī of Batavia. ${ }^{108}$ One year later, Said Oesman was encouraged to compose --which he did-a specific prayer $\left(d u^{\prime} \bar{a}\right)$ for the Dutch Queen Wilhelmina on the occasion of her ascent to the throne, 31 August 1889. As was to be supposed, Said Oesman invoked God's blessing on Queen Wilhelmina, praising the "just" colonial treatment of the Indies Muslims that allowed them to perform their religious obligations and kept the country living in safety and justice. ${ }^{109}$ Said Oesman read this $d u^{\text {' }} \bar{a}$ ' for the Queen in the mosque of Pekojan, his birth town, after the communal Friday prayer on 2 September 1898. He also distributed the copies of the $d u^{\prime a}$ ' to be read in Friday prayers throughout Java and Madura. ${ }^{110}$ This $d u^{\prime} a$ 'attracted some strong reactions from several factions of Muslim and Arab communities, both in the Indies and Singapore. Therefore, this $d u^{\prime} \vec{a}$ ' on the one hand led Said Oesman to gain a reward from the Dutch as a member of the Orde of the Netherlands Lion, but on the other hand, it led him to lose the prestige he had gained amongst the Indies Muslims. ${ }^{111}$

The Dutch imposition of such discriminative policies to the Arabs as the quarter and pass systems ${ }^{112}$ also explains Said Oesman's loyal political standing, which can be viewed as an adaptation demanded of a migrant. Like other fellow Hadramis and Arabs, his "Arabness" contributed to making him enjoy being highly-respected by the Indies Muslims. But it equally led him, and them, to be in a kind of limbo with regard to where his loyalties lay, a matter that became a hotly debated issue in the early twentieth century. ${ }^{113}$ For example, another well-known Hadrami 'älim of Aceh, Habīb 'Abd al-Raḥmān al-Ẓāhir, is regarded as

${ }^{108}$ Laffan, Islamic Nationhood, p. 88.

${ }^{109}$ N.J.G. Kaptein, "The Sayyid and the Queen: Sayyid 'Uthmān on Queen Wilhelmina's Inauguration on the Throne of the Netherlands in 1898", Journal of Islamic Studies, vol. 9, no. 2 (1998), pp. 159-61.

${ }^{110}$ Ibid., p. 160.

${ }^{111}$ Ibid., p. 173.

${ }^{112}$ Jong, "Dutch Colonial Policy", pp. 97-110; Mandal, "Finding Their Place", pp. $54-70$.

${ }^{113}$ N. Mobini-Kesheh, The Hadrami Awakening: Community and Identity in the Netherlands East Indies, 1900-1942 (Ithaca: Southeast Asia Program Publications, Cornell University, 1999). 
Jajat Burhanudin

having "aknowledged no loyalty to any particular country or people", 114 despite the fact that he played a major role in the political negotiation on Acehnese affairs.

\section{F. Concluding Remarks}

The above discussions provide us with ample evidence of the way scholarly studies contributed to the formulation of Dutch colonial policy on Islam and Muslims affairs. The experience of Snouck Hurgronje working for colonial service is an obvious example. He made a thorough study on Islam and the ways the Muslims practiced their religious belief in the socio-political arena of the Indies. And he dedicated his study for the Dutch agendas of colonizing Islam. He began his career departing to Mecca in 1884, with the main task to discover the roots of Islamic threat to the Dutch colonial government. He then delved into the studies further on Islam and Muslim lives in the Indies, and at the same time provided the Dutch authorities with advices on ways the Islamic issues be handled.

To a significant extent, Snouck Hurgronje succeeded. The pacification of Aceh is obvious evidence. His extensive knowledge on Islam and the inner-side of the Acehnese Muslims appeared as an intelligent source, which greatly contributed to the success of a military expedition to take the area --in which the ideology of jihad had been assumed as having a deep root-under direct control of the colonial administration. To be noted here is his providing the Dutch authorities with a comprehensive picture of Islam and the Muslims in the Indies, on the foundation of which the Dutch policy on Islam was formulated. Here, he asked the colonial government not to view Islam and the Muslims as a single entity. Instead, he presented a map where certain Muslim faction required certain policy suitable to its characters, different from the others.

What is also of special to note was his patronizing the penghulu. In addition to making them increasingly assimilated within the priyayi circle, it also mirrored the future vision of Snouck Hurgronje on the Dutch-Indies co-existence. In so doing, he attempted to free the Indies Muslims from what he saw as "the Medieval rubbish which Islam has been dragging along in its wake for too long", ${ }^{115}$ and therefore they would be capable of adapting to new ideas stemming from the western tradition of liberalism in the nineteenth century. In a series of lectures addressed to the Dutch

\footnotetext{
${ }^{114}$ Reid, "Habib Abdur-Rahman", p. 37.

${ }^{115}$ Hurgronje, Nederland en de Islam, p. 79.
} 
East Indian Academy of Administrative Studies in Leiden in 1911, Snouck Hurgronje promoted the ethical policy of "association", expecting from such emancipated Muslims as Hasan Moestapa --to mention only one- the future Indies as spiritually part of the Netherlands: "the birth of a Dutch state, consisting of two geographically distant but spiritually connected parts, one of which would be in north-western Europe and the other in Southeast Asia". ${ }^{116}$

Here, what Snouck Hurgronje did with the penghulu--also with Said Oesman of the Arab community — was a foundation for the future Ethical Policy the Dutch began to implement in the early twentieth centuryin the hands of W.F. Idenburg when he became the Minister of Colonies (1902-05, 1908-9, 1918-19). Snouck Hurgronje's will to direct the mental attitudes of the Indies people into modernity sourced the colonial policy on education that was purposed to producing emancipated native elite, the model to which the Indies people in general were expected to follow.

At certain points, the colonial project of Islam appeared to achieve what they might had expected. This was especially the case in the early twentieth century. As the Islamic reform began to be introduced to the Indies, new development began to occur, the most important of which was the rise of Muslim leaders, the reformists, who had the same voices as those presented by the new priyayi graduated from Dutch schools. And the reformist course was then followed, albeit sill distinctive, by the santri community under the leadership of the ulama of pesantren. The two Muslim voices of the period --the so-called the reformists and the traditionalists-became part of, and contributed to, the growing modernity of the Indies.

One final point to note is that modernity appears to have provided native elites with many options, including the idea of nation-state for the future Indies, Indonesia. And that was what really happened.

${ }^{116}$ Ibid. 
Jajat Burhanudin

\section{BIBLIOGRAPHY}

Alfian, T. Ibrahim, Perang di Jalan Allah, Perang Aceh 1873-1912, Jakarta: Pustaka Sinar Harapan, 1987.

Andaya, Barbara Watson and Virgina Matheson, "Islamic Thought and Malay Tradition: the Writings of Raja Ali Haji of Riau (ca. 1809-ca. 1870)", in Perceptions of the Past in Southeast Asia, ed. by David Marr and Anthony Reid, Singapore: Heinemann Educational Books, 1979.

Azra, Azyumardi, "A Hadrami Religious Scholar in Indonesia: Sayyid "Uthmān", in Hadrami Traders, Scholars and Statements in the Ocean, 1750s-1960s, ed. by Ulrike Freitag and William G. Clarence-Smith, Leiden: Brill, 1997.

Bakar, Abu (ed.), Surat-Surat Penting: Tuanku Hasyim Bangta Muda, Teungku Chi di Tiro, dan Teuku Umarpada Masa Perang Kolonial Belanda di Aceh, Banda Aceh: Pusat Dokumentasi dan Informasi Aceh, 1978.

Benda, Harry J., Continuity and Change in Southeast Asia: Selected Journal Articles of Harry J. Benda, New Haven: Yale University, 1973.

----, The Crescent and the Rising Sun: Indonesian Islam under the Japanese Occupation 1942-1945, The Hague: van Hoeve, 1983.

Boland, B.J. and I. Farjon, Islam in Indonesia: a Bibliographical Survey 16001942 with post-1945 Addenda, Doordrecht: Foris Publication, 1983.

Bosquet, G.H. and J. Schacht (eds.), Selected Works of C. Snouck Hurgronje, Leiden: Brill, 1957.

Burhanudin, Jajat (ed.), Ulama Perempuan Indonesia, Jakarta: GramediaPPIM UIN Jakarta, 2002.

Dijk, Kees van, "Colonial Fear: the Netherlands Indies and Malay Peninsula 1890-1918: Pan-Islamism and the Germano-Indian Plot", in Transcending borders: Arabs, politics, trade and Islam in Southeast Asia, ed. by H. de Jonge and N. Kaptein, Leiden: KITLV Press, 2002.

----, "From Head to Toe: Dress, Script, Culture and Identity", presented at the International Workshop on Southeast Asian Studies: Script as Identity Marker in Southeast Asia, Jakarta, 2004.

Drewes, G.W.J., "Snouck Hurgronje and the Study of Islam”, Bijdragen tot de Taal-, Land-en Volkenkunde, vol. 113, 1957, pp. 1-15 [doi: 10.1163/22134379-90002300].

Florida, Nancy K., Writing the Past, Inscribing the Future: the History of Prophecy 
in Colonial Java, Durham: Duke University Press, 1995.

Frijling, W., De Voornaamte Gebeurtenissen in het Begin van de 2de AtjehExpeditie, Door Atjehers Beschrieven, vol. 2, 1912.

Gobée, E. and C. Adriaanse (eds.), Ambtelijke Adviezen van C. Snouck Hurgronje 1889-1936, The Hague: Nijhoff, 1957.

Hisyam, Muhammad, Caught between Three Fires: The Javanese Pangulu under the Dutch Colonial Administration, Jakarta: INIS, 2001.

Hurgronje, C. Snouck, The Achehnese, trans. by A.W.S. O'Sullivan, Leiden: Brill, 1906.

----, Nederland en de Islam, 2nd edition, Leiden: Brill, 1915.

----, Verspreide Geschriften, Den Haag: Nijhoff, 1924.

----, Mekka in the Latter Part of the 19th Century, Leiden: E.J. Brill, 1931.

Jahroni, Jajang, "The Life and Mystical Thought of Haji Hasan Moestafa (1852-1930)", Master's Thesis, Leiden: Leiden University, 1999.

Jakub, Ismail, Teungku Tjbik Dhi-Tiro (Mubammad Saman): Pablawan Besar dalam Perang Aceh (1881-1891), Jakarta: Bulan Bintang, 1960.

Jaspan, M.A., "In Quest of New Law: The Perplexity of Legal Syncretism in Indonesia", Comparative Studies in Society and History, vol. 7, no. 3, 1965, pp. 252-66 [doi: 10.1017/S0010417500003674].

Jong, Huub de, "Dutch Colonial Policy Pertaining to Hadrami Imigrants", in Hadrami Traders, Scholars and Statements in the Ocean, 1750s-1960s, ed. by Ulrike Freitag and William G. Clarence-Smith, Leiden: Brill, 1997.

Kaptein, N.J.G., "The Sayyid and the Queen: Sayyid 'Uthmān on Queen Wilhelmina's Inauguration on the Throne of the Netherlands in 1898”, Journal of Islamic Studies, vol. 9, no. 2, 1998, pp. 158-77 [doi: 10.1093/jis/9.2.158].

Kartini, Tini, Biografi dan Karya Pujangga Haji Hasan Mustafa, Pusat Pembinaan dan Pengembangan Bahasa, Departemen Pendidikan dan Kebudayaan, 1985.

Kartodirdjo, Sartono, The Peasant Revolt of Banten in 1888: Its Conditions, Courses, and Sequel, The Hague: Martinus Nijhoff, 1966.

----, Elite dalam Perspektif Sejarah, Lembaga Penelitian, Pendidikan dan Penerangan Ekonomi dan Sosial, 1983.

Knysh, Alexander, "The Cult of Saint and Religious Reformism in Hadramaut", in Hadrami Traders, Scholars and Statements in the Ocean, 
Jajat Burhanudin

1750s-1960s, Leiden: Brill, 1997.

Koningsveld, P. Sj. van, Snouck Hurgronje dan Islam: Delapan Karangan tentang

Hidup dan Karya Seorang Orientalis Zaman Kolonial, 1st edition, Jakarta:

Girimukti Pasaka, 1989.

Laffan, Michael F., "Raden Aboe Bakar: An Introductory Note Concerning Snouck Hurgronje's Informant in Jeddah (1884-1912)", Bijdragen tot de taal-, land- en volkenkunde, vol. 155, no. 4, 1999, pp. 517-42 [doi: 10.1163/22134379-90003860].

----, Islamic Nationhood and Colonial Indonesia: The Umma Below the Winds, London: Taylor \& Francis, 2003.

Lubis, Nina H., Kehidupan Kaum Ménak Priangan, 1800-1942, Pusat Informasi Kebudayaan Sunda, 1998.

----, "Religious Thought and Practices of the Kaum Menak: Strengthening Traditional Power", Studia Islamika, vol. 10, no. 2, 2003 [doi: 10.15408/sdi.v10i2.629].

Mandal, Sumit Kumar, "Finding Their Place: A History of the Arabs in Java under Dutch Rule, 1800-1924”, Ph.D. Dissertation, Columbia University, 1994.

Matheson, Virginia, "Pulau Penyengat: Nineteenth Century Islamic Centre of Riau", Archipel, vol. 37, no. 1, 1989, pp. 153-72 [doi: 10.3406/arch.1989.2567].

Mobini-Kesheh, N., The Hadrami Awakening: Community and Identity in the Netherlands East Indies, 1900-1942, Ithaca: Southeast Asia Program Publications, Cornell University, 1999.

Moriyama, Mikihiro, "A New Spirit: Sundanese Publishing and the Changing Configuration of Writing in Nineteenth Century West Java", Ph.D. Thesis, Leiden University, 2003.

Palawa, Alimuddin Hassan, "The Penyengat School: A Review of the Intellectual Tradition in the Malay-Riau Kingdom", Studia Islamika, vol. 10, no. 3, 2003.

Pigeaud, G. Th., Literature of Java, The Hague: Martinus Nijhoff, 1967.

Pijper, G.F., Beberapa Studi tentang Sejarah Islam di Indonesia, 1900-1950, Jakarta: UI-Press, 1984.

Putten, Jan van der and Al-Azhar (eds.), Di Dalam Berkekalan Persahabatan: Letters from Raja Ali Haji, Leiden: Department of Languages and Cultures of Southeast Asia and Oceania Leiden University, 1995. 
Rahman, Fazlur, Islam, Chicago: University of Chicago Press, 1966.

Reid, Anthony, The Contest for North Sumatra: Atjeh, the Netherlands, and Britain, 1858-1898, Kuala Lumpur: University of Malaya Press, 1969.

----, "Habib Abdur-Rahman az-Zahir (1833--1896)", Indonesia, vol. 13, 1972, pp. 37-60.

Roff, William R., "Islam Obscured? Some Reflections on Studies of Islam \& Society in Southeast Asia", Archipel, vol. 29, no. 1, 1985, pp. 7-34 [doi: 10.3406/arch.1985.2215].

Ronkel, Ph. S. van, "Aanteekeningen over Islam en Folklore in West- en Midden-Java: uit het Reisjournal van Dr. C. Snouck Hurgronje”, Bijdragen tot de Taal-, Land-en Volkenkunde, vol. 101, 1942 [doi: 10.1163/22134379-90001256].

Rosidi, A., "Menjejaki Karya-Karya Haji Hasan Mustapa", in Warisan Intelektual Islam Indonesia: Telaah atas Karya-Karya Klasik, ed. by Ahmad Rifa'i Hasan, Bandung: Mizan, 1987.

Said, Edward, Orientalism: Western Conceptions of the Orient, revised edition, London: Penguin, 1995.

Schmidt, J., Through the Legation Window, 1876-1926: Four Essays on Dutch, Dutch-Indian and Ottoman History, Istanbul: Nederlands HistorischArchaeologisch Instituut te Istanbul, 1992.

Simuh, Mistik Islam Kejawen Raden Ngabehi Ranggawarsita: Suatu Studi terhadap Serat Wirid Hidayat Jati, Yogyakarta: IAIN Sunan Kalijaga, 1983.

Solomon, Wendy, "Text and Personality: Ajip Rosidi in Search of Haji Hasan Mustapa", Indonesia Circle, vol. 14, no. 41, 1986, pp. 11-27 [doi: 10.1080/03062848608729648].

Steenbrink, Karel A., Beberapa Aspek tentang Islam di Indonesia Abad ke-19, Jakarta: Bulan Bintang, 1984.

----, Dutch Colonialism and Indonesian Islam: Contacts and Conflicts 1596-1950, Amsterdam: Atlanta GA, 1993.

Suminto, H. Aqib, Politik Islam Hindia Belanda: het Kantoor voot Inlandsche Zaken, 1899-1942, Jakarta: LP3ES, 1985.

Tsuchiya, Kenji, "Javanology and the Age of Ranggawarsita: An Introduction to the Nineteenth Century Javanese Culture", in Reading Southeast Asia, ed. by Audrey Kahin, Ithaca: Southeast Asia Program Cornell University, 1990.

Uhlenbeck, E.M., A Critical Survey of Studies on the Languages of Java and Al-jāmíah, Vol. 52, No. 1, 2014 M/1435 H 
Jajat Burhanudin

Madura, 's-Gravenhage: Nijhoff, 1964.

Veer, Paul van 't, Perang Aceh: Kisah Kegagalan Snouck Hurgronje, Jakarta: Grafitipers, 1985.

Wehr, Hans, A Dictionary of Modern Written Arabic, ed. by J. Milton Cowan, Beirut: Librairie du Liban, 1974.

Wertheim, W.F., "Counter-Insurgency Research at the Turn of the Century: Snouck Hurgronje and the Acheh War", Sociologische Gids, vol. 19, 1972, pp. 320-8. 